\title{
My Child Deus
}

\section{Grammar versus Theology in a Japanese Christian Devotional of 1591}

\author{
Patrick Schwemmer \\ Princeton University \\ pschwemm@princeton.edu
}

\begin{abstract}
Manoel Barreto's Japanese miscellany contains "Dialogues on the Instruments of the Passion," which show how closely complex cultural structures are intertwined with the machinery of grammar. Featuring the Virgin Mary and Mary Magdalene, the dialogue sublimates maternal and erotic energies in turn while contemplating the usual series of violent instruments. The speeches display not only linguistic competence but literary skill in their use of the personless poetic flow of renga linked verse and the noh theatre. However, the Latinate double-entendre on filho [son (of God and of Mary)] misfires because the Japanese language uses honorifics to maintain stable intersubjective reference and so cannot simultaneously refer to Jesus as both a superior and an inferior. This failure is supplemented with Portuguese marginalia and bold catachresms. Mary Magdalene's erotic sublimation is presented with less success as excessive literalism frequently produces comedy. Then, an appendix entitled "The Meaning of the Passion" repeats the exercise in halting, clinical prose marred by occasional errors of grammar and style, cataloguing the instruments as dogu (implements), the word used for art objects in the tea ceremony, and outlining their theological function with attention to precise doctrinal formulations. Frequent use of Portuguese loanwords conveys a (justified) anxiety with regard to the ability of the Japanese language to transmit (European) truth. I identify the dueling Zeami and Aquinas of this piece as a Japanese convert and his or her European mentor, then venture a hypothesis as to the precise historical figures behind these voices in tension.
\end{abstract}

\section{Keywords}

Japan - Jesuit literature - linguistics - noh theater - renga - devotio moderna 
The early-modern, Portuguese-sponsored Jesuit mission to Japan left behind a body of Christian literature in Japanese whose alphabetic texts have been a treasure trove for linguists, its existence a point of pride for Christian sectarians, and its content rich material for historians. However, linguists have been content to describe static forms, religious commentators have only addressed such data as they find inspiring, and historical treatments rush by design to the content, so that most of these materials have yet to be read closely as literature. ${ }^{1}$ As a preliminary to a full-length study of the operations by which these linguistic artifacts produced their intended (and unintended) ideological and historical effects, ${ }^{2}$ I introduce here "Some Dialogues on Some Instruments of the Passion of Our Lord Jesus Christ" from the Barreto miscellany in the Vatican Library, ${ }^{3}$ a devotional meditation whose poetics illustrate the challenges inherent in adapting the cultures of Latin Christendom to Japan, challenges which arise from the mutually constitutive relationship between complex cultural structures and the machinery of grammar. The "Dialogues" have a double structure which shows the collaborative yet contested nature of the translational nexus built by the European Jesuits and their Japanese converts, as two opposing voices are seen to prioritize good Japanese composition on the one hand and doctrinal orthodoxy on the other. These voices inscribe social relationships of pedagogy and colonial subjecthood, and they will allow me to make a tentative attribution of authorship. ${ }^{4}$

The Barreto miscellany is a 382 -folio manuscript in the hand of Manoel Barreto, S.J. (c.1564-1620), containing a variety of basic Catholic texts-gospel readings for the entire church year, miracle stories, devotional meditations, and saints' lives_-handwritten with a quill pen on Japanese paper, in a leather

1 Tadao Doi, "Das Sprachstudium der Gesellschaft Jesu in Japan im 16. und 17. Jahrhundert," Monumenta Nipponica 2, no. 2 (July 1939) exemplifies the linguistic turn; Hubert Cieslik, S.J., "Shūkyō shisō shi kara mita Bareto shahon," Kirishitan kenkyū 7 (1962), the theological; and George Elison, Deus Destroyed: The Image of Christianity in Early Modern Japan (Cambridge: Harvard University Press, 1991), the historical. William J. Farge, S.J., The Japanese Translations of the Jesuit Mission Press, 1590-1614: De imitatione Christi and Guía de pecadores (Lewiston, NY: Edwin Mellen, 2002) lays the groundwork for this study, but it limits its attention to the "successful adaptation" (7) of "theologically sophisticated" (13) works.

2 "Samurai, Jesuits, Puppets, and Bards: The end(s) of the kōwaka ballad" (Ph.D. Diss., Princeton University, 2015), forthcoming.

3 Vatican Library, Reg. lat. 459 , ff. $78-82^{\text {v }}$, transliterated into Japanese script in "Warera ga shu Kirisuto go-junan no dōgu ni taisuru jakkan no taiwa," ed. Morita Takeshi, Kirishitan kenkyū 7 (1962).

4 Professors Leonard Barkan, Tom Hare, Martin Collcutt, Andrew Watsky, Eileen Reeves, and Mia Mochizuki provided indispensable guidance in this inquiry. 
binding whose markings match those of one known to originate in Goa. ${ }^{5}$ Its body text is in Japanese, with titles, marginalia, cross references, and indices in Portuguese, Latin, and Japanese, all using the Roman alphabet. Barreto's dedication dates it to 1591, one year after his arrival in Japan, so it would seem to have been an expedited production and a first harvest of the fruits of ten years of Alessandro Valignano's systematic exchanges of language and culture. ${ }^{6}$ Moreover, pagination marks are found in the margins, and multiple sections survive in edited form in printed chapbooks of 1591 and 1607 , as well as several handwritten copies in Japanese script, ${ }^{7}$ so Josef Schütte, S.J., who discovered it in 1940, surmises that many of its sections were printed as core performance notes for masses, sermons, and debates by missionaries across Japan. ${ }^{8}$ If this is true, then Barreto's texts are representative of the precise words that a great number and variety of Japanese heard from the Jesuits. Furthermore, Luis Froís, S.J. (1532-1597) describes public devotionals, recited by children holding props representing the instruments of the Passion, organized by a Xavier-connected irmão [lay brother] at Yamaguchi in 1552, then by Gaspar Vilela at Nagasaki in $1570,{ }^{9}$ so there was an established use for texts like the "Dialogues" when Barreto transcribed them.

The five-folio "Dialogues" are composed of precisely such meditations on the instruments of the Passion. Speeches on each are assigned to either the Virgin Mary or Mary Magdalene, though these do not particularly answer one another, and one figure sometimes speaks multiple times in succession, so that the suitability of the name "dialogue" might be questioned. However, the name is perfect in that this first rehearsal of the instruments is followed by a reprise with differences that place the two versions in a dialogue with one another. Before addressing this structural issue, I will discuss the particularities of the text's surface.

5 Joseph Schütte, S.J., "Christliche Japanische Literatur, Bilder und Druckblätter in einem Unbekannten Vatikanischen Codex aus dem Jahre 1591," AHSI 9 (1940): 232.

6 Elison, Deus Destroyed, 51.

7 "Sanctos no gosagyō," "The Passion of Christ," "Spiritual shugyō," in Laures Rare Book Database Project and Virtual Library, New Electronic Edition, ed. Johannes Laures, S.J. (laures.cc.sophia .ac.jp, accessed 8/2013).

8 Schütte, "Vatikanischen Codex," 1940, 228. The low survival rate of printed versions would be easily explained by the subsequent persecutions.

9 Luís Froís, S.J., História de Japam, ed. José Wicki, S.J. (Lisbon: Biblioteca Nacional de Lisboa, 1976 [1594]), quoted in Cieslik, "Bareto shahon" (1962), 77, 79. Froís first arrived in Japan in 1563, so he could only have seen Vilela's production. I do not follow Cieslik's assumption of a unitary tradition behind the "Dialogues," these earlier public devotions, similar devotions performed in Europe at the time, and the kōwaka mai ballad tradition, nor his claim that "all churches" were practicing "it." 
The opening speech, assigned to the Virgin Mary, shows both the catachrestic nature of this enterprise and the resourcefulness with which it is undertaken. Because my analysis will center on a grammatical structure called honorifics, I mark these in my translations by capitalizing predicates. ${ }^{10}$

[78] ycani vaga co nite maximasu Vó Aruji, mizzucara cono von cotouo qiquyori cocoro vodoroqi midarete, arumo arareneba fitomeuo sarani sabacaraçu, banminno nacauo vaque xinoguite, coremade coremade mayritaruvo goranjitamo ca?

How now, O Lord who Art my child! Having heard for myself What has happened to you, my mind is shocked and scattered, for I am and yet I cannot be, ${ }^{11}$ and so, caring not at all to keep composure before the eyes of others, pushing my way through among the multitude-do you See I've come, I'm here, I'm here?

The first word, ycani [How now!], is a greeting used to ask politely for attention, but it is used here in the manner of the Latin vocative case. Japanese has no structures corresponding to Indo-European cases, but the Jesuits analyzed according to what they knew, creating paradigms which João Rodrigues, S.J. (1561-1634) would later codify in his grammar of 1604 , which gives the same word icani for the vocative:

Declinação pera todos os nomes substantivos, \& pronomes primitivos.

Nominativo. Aruji. |, Arujiua, ga, no, yori, Senhor, ou dono.

Genitivo. Arujino, ga.

Accusativo. Arujiuo, uoba, ua, ga.

Vocativo. Aruji, icani Aruji.

Ablativo. Arujiyori, cara, ni. ${ }^{12}$

This opening address, then, displays formulaic construction, but given the centrality to East Asian literacy of xenographic formulae for reading logographs aloud in any vernacular by translating them on the fly-whether they were written by speakers of the many Chinese languages, Japanese,

10 There are also humilifics, but these do not figure in my discussion, so I do not mark them. In hopes of approaching the effect of the text on its original intended audience, I leave Portuguese and Latin untranslated.

11 A colloquialism expressing inconsolable preoccupation.

12 João Rodrigues, S.J., Arte da lingoa de Japam / Nihon dai bunten, trans. Doi Tadao (Tokyo: Sanseidō, 1955 [1604]), frontispiece, 7 [f. 1]. 
Vietnamese, or Mongols - this quality does not necessarily indicate European authorship. ${ }^{13}$ In fact, icani is also common as a salutation in the noh theatre, so it is not out of place here.

Indeed, the passage as a whole shows not only linguistic competence but literary skill. Japanese lacks person, number, and gender as grammatical phenomena, and it is an exclusively left-branching language, which means that each word or phrase becomes the grammatical antecedent of those that came before. Its traditional poetry strings together predicates using a great variety of subordinating and coordinating conjunctions, sometimes pivoting ambiguously among multiple points of reference in such a way as to produce kaleidoscopic shifts of consciousness from moment to moment. ${ }^{14}$ Here the subject of every clause is unambiguously Mary, but the absence of pronouns and predicates specifying person makes the discourse hew closer to an individual stream of consciousness than if she kept specifying "I" from an objective point of view: her subjectivity is the only reality. The long sentence in which she forces her way through the crowd performs her agitated state of mind as it winds breathlessly from clause to clause-while piling up a hypotactic stack which balances like an upside-down pyramid on that final, quotative frame: “...goranjitamo ca?" [Do you See...?]. Strictly speaking this modifies everything else, back to the second phrase-so that a more literal rendering would read, "Do you See that I, having heard [...]," etc. This poetics of shifting yet cumulative frame of reference has immediate antecedents in renga linked verse and the noh theatre, where the playwright Zeami describes a "Woman's mode" which creates "a state of aesthetic derangement." 15 Numerous thematic precedents can be found in contemporary literature for Mary's distressed motherly sentiment: the mother of the doomed child emperor in the Tale of the Heike, ${ }^{16}$ the destitute mothers miraculously reunited with lost children in noh plays like "The Sumida River,"17 or Yoshitsune's mother Tokiwa in the tragic cycle

13 David Lurie, "Kundoku: Reading, Writing, and Translation in a Single Script," Realms of Literacy: Early Japan and the History of Writing (Cambridge: Harvard University Press, 2012).

14 Robert H. Brower and Earl Miner, Traditional Japanese Court Poetry (Palo Alto: Stanford University Press, 1961), 6-13.

15 Zeami, Nihon shisō taikei: Zeami/Zenchiku, ed. Omote Akira and Katō Shūichi (Tokyo: Iwanami Shoten, 1974), 138; Tom Hare, Zeami's Style: The Noh Plays of Zeami Motokiyo (Palo Alto: Stanford University Press, 1986), 132.

16 "Kanjō no maki," Shin Nihon koten bungaku taikei: Heike monogatari, eds. Kajiwara Masaaki and Yamashita Hiroaki (Tokyo: Iwanami shoten, 1993); The Tale of the Heike, trans. Royall Tyler (New York: Penguin, 2012), 688.

17 Kanze Motomasa, Shin Nihon koten bungaku taikei: Yōkyoku hyakuban, ed. Nishino Haruo (Tokyo, Iwanami shoten, 1998), 338; Japanese Nō Dramas, trans. Royall Tyler (New York: Penguin, 1992), 251. 
that bears his name. ${ }^{18}$ Whether the authors were conscious of these or not, Mary's breathless hypotaxis makes it impossible that they were ignorant of something like Zeami's "aesthetic derangement."

However, the same personlessness that makes the above play possible also causes a classic trope to misfire, for Japanese relies primarily on honorifics for stable intersubjective reference. As Valignano explains in his Sumario of 1580:

Depending on the status of the person or the things one must use higher or lower, respectful or disdainful words. [...] If one speaks or writes differently than they are accustomed to do, one makes with them a laughable and inconsiderate impression, as if among us one were to speak incorrectly, with many mistakes in his Latin. ${ }^{19}$

The problem is that for Mary, Jesus with his dual nature is both a superior and an inferior, so the usual play on "son" is impossible: either a given predicate has an honorific or it does not; in Japanese there can be no ambiguity about this. In the opening sentence above, the "Dialogues" address this by naming the two relationships separately and then equating them with a copula: uaga co nite maximasu Võ Aruji [O Lord who Art my child]. However, changing the honorific level makes it sound as if there are two separate people under discussion, and so the phrase hovers on the edge of unintelligibility even if we understand the complicated relationship between Mary and Jesus. Equation takes work: even the formula for identity, "A=A," contains two terms which must be considered in relation, ${ }^{20}$ and here we have two identities for Jesus $(\mathrm{a}=\mathrm{A})$, so it requires even more effort to apply the equation and forget the duality. In English, a similar confusion can be created with gender by a sentence like, "John went to Thailand, and she came back a month later" - even if we understand that John has had a sex change, stable reference is disrupted: so it is with the mobile honorifics necessitated by the dual nature of Christ.

Later, in her speech on the whipping pillar, the Virgin switches the honorific level without a copula, speaking one sentence in honorifics and the next in unmarked, familiar language.

$\left[7^{\mathrm{v}}\right]$ Vó co $\left(f^{\circ}\right)$ no miyori nagaretamo Vó chi coreni somi tamayeba fanaregataqu uomoy tatemaccuru. Vaga uomoygono (^dilectos fil.) vó fadayeuo

18 Shin Nihon koten bungaku taikei: Gikeiki, ed. Kajiwara Masaaki (Tokyo: Shōgakukan, 200o), 20; Yoshitsune, trans. Helen McCullough (Palo Alto: Stanford University Press, 1966), 70.

19 Cap. 2. Jesuítas na Ásia, 49-IV-56, f. 64v , quoted in Doi, "Sprachstudium," 1939, 111.

20 Martin Heidegger, Identität und Differenz (Berlin: Verlag Günther Neske Pfullingen, 1957). 


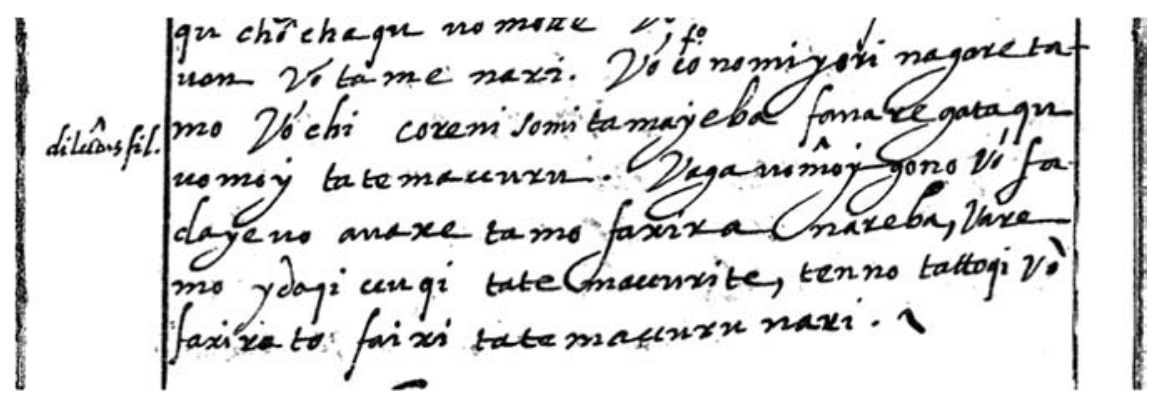

FIGURE 1 Reg. lat. 459, by permission of Biblioteca Apostolica Vaticana, with all rights reserved. (c) 2013 Biblioteca Apostolica Vaticana

auaxe tamo faxira nareba, varemo ydaqi ccuqi tatemaccurite, tenno tattoqi vò faxira to faixi tatemaccuru nari.

If the Blood that Flows from the body of the Child $\left(f^{\circ}\right)$ could seep into me, I feel we would never part. Since it is the pillar against which this dear child of mine (^dilectos fil.) Presses his Skin, I too will embrace it and worship it as the precious Pillar of heaven.

Again the honorific change is problematic: it sounds as if there are two sons, one honored and one beloved. This time, as if in hopes of bridging the gap, a graphic link is introduced between the honorific and unmarked versions of $c o$ [子] (child; the word is not gendered): Portuguese glosses are added to both instances, each containing the same word filho [son] but also suggesting each of its two meanings in turn: filho [Son] is abbreviated $f^{o}$ as it often is in doctrinal formulations, and dilectos filho [dear son] stresses the human relation. Further on, an even bolder catachresm is ventured:uaga uonco Deus [my Child Deus] (f. 79) applies both "my" and an honorific to co [child], resulting in an invalid construction: one's own children are no more given honorifics in Japanese than they are called "yours" in English. Empresses in the Tale of Genji, for example, use honorifics on their own imperial children, but in that case a system of double honorifics is exceptionally created to avoid confusion. Overall, the Virgin's speeches use Japanese poetics to great effect, but their attempt to reproduce the European play on "Son" strains the language to the breaking point.

As the speeches of the Virgin spiritualize maternal sentiment, those of Mary Magdalene take erotic sublimation for their theme. Precedents for such a figure in Japanese literature would include, among many long-suffering women, Yoshitsune's lover Shizuka: she and his mother Tokiwa, mentioned above, are a similar pair of maternal and erotic interlocutors through whom that tragic 
hero's sufferings are processed in the bardic tradition. ${ }^{21}$ In the "Dialogues," Mary Magdalene's speeches focus throughout on the sensual properties of each instrument: the tight squeezing of the rope, the pain of the thorns which pierces to the core, the pounding of the hard hammer. In Japanese poetry, horses and grass or the beating of waves against the shore often stand in for lovers and their activities, and although the Jesuits show no particular interest in such tropes in the documentary record, the technique has translated here well enough.

[79 $]$ Satemo, tattoqi uon crux cana; Core coso vaga fucaqu uomoy tatemaccuru Vó Arujino vó ytomaxiqixisuru no Vó nemurini fuxitamo yauara $(\wedge c a)$ naru Von yuca (^toco-leito) nare. [80] ymayori nochiva coreuo coso vaga quccurogui toua mochytatemaccuru beqere.

$\left[79^{\mathrm{v}}\right]$ Oh, what a precious Crux! This is the soft Bed (^matting-leito) on which the Lord for whom I long so deeply lies in Sleep of agonizing death. [8o] From now on this, this is what I will use to lie back and let myself go.

If the theme of erotic mysticism was not already apparent, surely this would have gotten the reader there.

Nevertheless, Mary Magdalene's speeches fall at times into comedy due to a too-literal imitation of their European models. For example, sweetness is not especially valued in Japanese culture: metaphorical meanings of the word for "sweet" include "weak," "childish," and "frivolous," and any association with pleasure in general is not prominent. Unfortunately, attributions of "sweetness" to the sufferings of Jesus rely on just such an association, and so when literally translated as here, the figure cannot help but evoke the image of Mary Magdalene lustily eating nails.

[8o] Satemo ajjiuay fucaqu amaqi cugui cana? Vó tasqeteno mite to miaxino sujji no uoqi nacauoytamaxiqumo ccuranuqi tatemaccuritareba catacu nigaqeredomo amaqi gotayxet uomotte Vó crusni somiccuqitamay von ynochino vchiniua ccuini Vó crux uo fanare tamauazaru dogu nareba macotoni amacu uoboyuru nari.

Oh, what deeply flavorful and sweet nails! They are hard and bitter in that they painfully pierce the sinewy Hands and Feet of the Helper, but

21 Shinpen Nihon koten bungaku taikei: Gikeiki, ed. Kajiwara Masaaki (Tokyo: Iwanami shoten, 1999); Yoshitsune: A Fifteenth-Century Japanese Chronicle, trans. Helen McCullough (Palo Alto: Stanford University Press, 1966), chs. 5-6. 
because they are the implements which stick him fast in sweet Cherishing to his Crux so that as long as he Lives he will never Leave it, I experience them as truly sweet.

The infelicity would have been evident to any Japanese author of the passage, but such an author might have been under pressure from European mentors to translate literally.

Whether or not a struggle between the literal and the poetic or source and target languages can be seen under the surface of this first set of meditations, just such a struggle is made explicit by the presence of a second set under the title Gopassion no cotouari [The Meaning of the Passion]. This second section is notable for its logical formulae and linguistic conservatism: though written in Japanese, it treats the language like a wild horse that might at any moment carry it off into uncharted territory.

The tone is explanatory from the outset: the Passion is a transaction between "Our Lord JESUS $\mathrm{X}^{\mathrm{o}}$ " and Deus Padre [81], necessitated because the sin of "Adam of the beginning and his wife" $\left[8 \mathbf{1}^{\mathrm{v}}\right]$ had made humanity "hereditary vassals (fuday [譜代]) of tengu" [82 $2^{\mathrm{v}}$. Tengu are mischievous goblins who appear in Japanese literature as enemies of Buddhism, embodiments of religious pride, or morally neutral allies of trickster figures. I suspect that the Jesuits may have connected them to the devil because of the resemblance between ballads about the renegade Yoshitsune learning the arts of war by sparring with friendly tengu in the mountains and the story of Jesus tempted by the devil in the wilderness. Unlike Xavier's use of Dainichi for Deus, the use of tengu for "devil" continued up until the expulsion. In "The Meaning of the Passion," the passion of the Marys is replaced by a clinical appraisal of each object for its theological effect: the hammer is "the implement which Drives his inescapable Cherishing into us human beings" [82]. The name by which this text calls its subjects deepens its resemblance to a carefully curated exhibition: $\operatorname{dog} u$ [道具] (implement) is the word for the art objects displayed in the tea ceremony, a central medium of contemporary elite social interaction. ${ }^{22}$ This word also appears in the dialogues above, but here it is repeated for each object. An interest in precise numbers is also evident: we learn that at the pillar Jesus "received some five thousand six hundred strokes with the rod" [81], suffered on the cross for three hours [82], and had three nails driven into him $\left[82^{\mathrm{v}}\right]$. To the ten instruments of the earlier dialogues, the "Meaning" adds the

22 Valignano recommended that all Jesuit residences be equipped with tea rooms: Josef Schütte, S.J., Valignano's Mission Principles for Japan, trans. John J. Coyne (St. Louis: The Institute of Jesuit Sources, 1985), 45-46. 
taque [bamboo] - the reed which Jesus is made to hold while he wears the crown of thorns - and the pliers with which the nails were pulled out of his limbs, for a felicitous total of twelve.

Finally, "The Meaning of the Passion" contains errors of grammar and style. Its first sentence uses the particle yori for the Latin ablative case, as in Rodrigues's table above-JESU $X^{\circ}[\ldots]$ Dś Pe yori cruxni cacare tamayeto sadametamayeba $[81]$ —except that here the passive construction "Being commanded by Deus Padre" is meant. A passive auxiliary on the verb and $n i$ on the agent would have expressed this, but instead the verb has been left in the active voice and yori appended to the agent, yielding, "JESU $\mathrm{X}^{\circ}$, Commanding from Deus Padre to Be hung on a crux [...]." A similar error puts yori on the agent of a causative, yielding, "Thirty mon in silver coin is the money that [the bamboo, i.e., the reed] Caused from the criminal Judas to bear" $\left[82^{\mathrm{v}}\right]$. Honorific infelicities also occur. In, "They roughly peeled off his Skin, [...] and so it Is an Undergarment (hadaginu, "skin-cloth") to which his cut Flesh Is stuck," the pun on hadaginu and the grating superfluity of honorifics-four out of five words in the last clause-convey a flippant, studied attitude that a native speaker could hardly have found appropriate. Use of Portuguese words is also

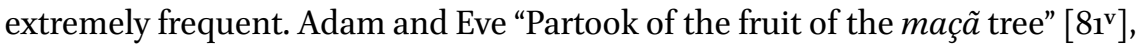
but Jesus's death "Frees us from the suffering of iustiça in inferno" [82], to be "brought back to life in graça" $\left[8 \mathbf{1}^{\mathrm{v}}\right]$ and "gloria" [82]. The fundamental choice between translating and introducing loanwords is influenced by various factors: maçã [apple] seems meant to hide from the uninitiated the teaching that evil entered the world through the eating of a common apple, but other than that it seems clear that the Portuguese reflect an anxiety regarding the ability of the Japanese language to transmit truth, on the part of whoever added this section. Considering problems like the honorific paradox above, this anxiety is legitimate: Giorgio Agamben has shown how seemingly mundane categories like "person," "nature," and "substance" were forged in and through the Christological and Trinitarian debates of the first millennium CE: persona, for instance, once meant "mask." ${ }^{23}$ Accordingly, there is a sense in which any truth that a language transmits is inseparable from the grammar and lexicon of that language.

Another Latinate loanword holds a clue to the historical function of this text. In the "Meaning of the Passion," Japanese buchi [whip], used earlier in the dialogue, is replaced by disciplina as a word for "whip."

23 Giorgio Agamben, Categorie italiane. Studi di poetica (Venice: Marsilio, 1996), $23 \mathrm{ff}$. 
$\left[8 \mathrm{1}^{\mathrm{v}}\right] \sim$ Disciplina

Cono disciplinaua Vó Aruji JESU Xo no Vó miuo vchiyaburi tatemaccuritaru dogu nari Core sunauachi inferno nite vqubeqi curuximino caxaquuo nogaxitamo xiruxi nari.

This disciplina is the implement by which the Body of our Lord JESU Xo Is beaten and broken. That is to say, it is the sign which Frees us from the denunciation of suffering which we were to receive in inferno.

From this it seems clear that self-flagellation was part of the use of this text, and indeed we find copious reference to the practice, public and private, as early as $1557 .{ }^{24}$ Indeed, after the expulsion, mass self-flagellation became a prominent feature of public protests by the Christians of Nagasaki, ${ }^{25}$ and so this piece is a part of the mechanism which first inculcated this practice in such a large group of people.

So far I have addressed questions of person, gender, and honorifics; I will end on one of number. ${ }^{26}$ We have seen that the "Dialogues" have a dual structure, but is that why their title is in the plural (Colloquios)? Hubert Cieslik, S.J. assumes so and groups both sections of the piece together with a meditation on the Nativity elsewhere in the Barreto miscellany for a corpus of three "dialogues" - a word he uses as a synonym for "introspective meditations in the style of Devotio Moderna."27 However, although the influence of Devotio Moderna is certainly pronounced in all of these, neither that Nativity piece nor the "Meaning of the Passion" is a dialogue, except in the sense that every text makes a (one-sided) address to its reader. Accordingly, I read the plural in the title as referring simply to the series of exchanges between the Marys, with the "Meaning of the Passion" corresponding to nothing in the title. In this light the latter reads even more like an afterthought, which begs the question: how many authors did the "Dialogues" have? We know that the 1595 LatinPortuguese-Japanese dictionary, for example, was written by a team of three Europeans and two Japanese, ${ }^{28}$ but can we know who wrote which words? Even when a text is securely attributed, as with Rodrigues's unsourced Japanese

\footnotetext{
24 Luis Froís, Historia de Japam, ed. Wicki, 1:25, 89, 109, 123, etc.

25 Elison, Deus Destroyed, 1991, 161.

26 This concluding section grows from Mia Mochizuki's comments on a version of this article presented at the International Conference of the Centro de História de Além-Mar, Lisbon, $7 / 2013$.

27 Cieslik, "Bareto shahon," 1962.

28 Letter of Pero Gomez, quoted in Schütte, “Unbekannten Codex," 1940, 234.
} 
examples, it is always potentially in the voice of any speaker he had ever heard and every text he had ever read. With the "Dialogues," however, so many clues point in the same direction that it is possible to pose a solid theory: namely, that the first, dialogic part with its skillful poetry was composed by a Japanese convert, while the halting, Euclidean prose of the second was supplied by his or her European mentor. ${ }^{29}$

Many such missionary/convert pairs are known to history, beginning with Xavier and his native informant Anjirō in the 1540s, and it happens that one of the best-documented of these is closely connected with the Barreto miscellany, in which the "Dialogues" survive. When Valignano arrived in Japan in 1590 with Barreto and the printing press, he had just finished an eight-year public relations campaign in which he paraded around Europe four youths from Kyūshū, presenting them to kings and popes as a carta viva [living letter] from Japan and forging testimonials in their names extolling the superiority of Western Christendom and the necessity of more generous missionary funding if the Japanese were to be added to its ranks. ${ }^{30}$ Among the members of this "boys' embassy" were a youth of fourteen from a family of strongmen in the Ōmura domain, baptized Martinho Hara (c.1570-1629), and an older, Portuguese priest named Diogo de Mesquita, S.J. (1553-1614). As Mesquita recalls in a letter of 1613, he had acquired the mission press on Valignano's orders in Lisbon in 1586, and Hara, now a Jesuit priest, had composed and revised many of its bestattested texts. ${ }^{31}$ With the final suppression of Christianity in 1614, Mesquita fell ill and died on the shores of Nagasaki, and Hara fled to Macao with the printing press in tow, and so these two seem to have remained the Achilles and Patroclus of the press to the end - though who was Achilles and who Patroclus would be difficult to say. Promotional materials for the "boys' embassy" are unreliable, but Froís's account records a 1584 visit by the boys and their handlers to Luis de Granada, O.P. (1505-1588), upon which "they showed him his books translated into the language and script of Japan,"32 and indeed, all of the works attributed to Hara by Mesquita are precisely translations of Granada: Diego Pacheco, S.J., suggests plausibly that those shown to Granada himself may also have been composed and/or revised by Hara and Mesquita aboard ship.

29 The participation of women was not encouraged by the Jesuits, but Japanese Christian lay women were nevertheless active as catechists: Haruko Nawata Ward, "Jesuits, Too:Jesuits, Women Catechists, and Jezebels in Christian-Century Japan," in John W. O'Malley, S.J. et al., eds., The Jesuits II: Cultures, Sciences, and the Arts 1540-1773 (Toronto: University of Toronto Press, 2006).

30 J.S.A. Elisonas, "Journey to the West," Japanese Journal of Religious Studies 34, no. 1 (2007), 32.

31 Diego Pacheco, "Diogo de Mesquita, S.J. and the Jesuit Mission Press," Monumenta Nipponica 26, no. 3 (1971): 439-41. Quoted in Pacheco, "Mesquita," 440. 
Moreover, the hagiography section of the Barreto miscellany also contains material by Granada, ${ }^{33}$ and so it is possible that some of its contents were composed not in Japan during Valignano's absence but by Hara and Mesquita during their journey to Rome and back. Barreto joined them on their return trip in Goa, where they would arrive in May of 1587 , and I have mentioned that his miscellany is bound in Goan leather. Many scenarios can be imagined to account for this feature. The miscellany could have been re-bound on its way to Europe in the mid-seventeenth century, where by ways unknown it ended up in the collection of Christina, queen of Sweden, who donated it to the Vatican Library. But it is also possible that it had its present binding before Barreto first left Goa with Valignano and the boys in early 1590, arriving in Nagasaki in July. ${ }^{34}$ Supposing that 1591 is the miscellany's date of completion, however, seventeen months is a short time to copy 764 pages in a new language; the three-year window afforded by a 1588 start date sounds more reasonable. Barreto would have had more time for this project before arriving in Japan, but even assuming an even pace, up to two thirds of the miscellany would have had to be copied between Goa and Japan. The "Dialogues" occupy folios 78 to $82^{\mathrm{v}}$ out of 382 , so unless the pages have been rearranged, they are likely to have been copied from materials on the boat - and such Japanese Christian texts as are known to have been on the boat were possibly translations by Hara and Mesquita.

The evidence permits no more than hypothesis, but it is instructive to let these two stand in for the dueling Zeami and Aquinas in "Some Dialogues on some Instruments of the Passion of Our Lord Jesus Christ." Anyone who, like Hara, had committed to a foreign ideology would have been invested in giving it a pleasing and intelligible voice in his own language, even if its very foreignness also held a certain allure for him. Meanwhile, one in Mesquita's position would likewise have been eager to clothe his message in authentic native garb but also anxious to ensure that it remained the same message. Accordingly, he might well have added doctrinal supplements to pin it down-even if this meant that his readers would have to learn a sizeable Latinate lexicon in order to understand him. Each speaks in a voice formed in dialogue with the other, performing before the dual audience of their respective communities. We have seen how in their search for harmony with each other they are pulled upon by diverse tensile structures: whoever they were, "now the wheel of karma brings them face to face once more." ${ }^{35}$

\footnotetext{
33 Laures, "A manuscript compiled by Manuel Barreto, S.J.," Database.

34 Schütte, "Vatikanischen Codex," 233-35.

35 Zeami, "Atsumori," Shin Nihon koten bungaku zenshū: Yōkyokushū, eds. Koyama Hiroshi and Satō Ken'ichiro (Tokyo: Shōgakukan, 1998), 231, my translation; see also Japanese Nō Dramas, trans. Tyler, 48.
} 


\section{Translation}

[78] Alguns colloquios a alguns Instrumentos da paixão de Christo nosso Senhor. Nossa Senhora.

How now, O Lord who art my child! Having heard for myself What has happened to you, my mind is shocked and scattered and, caring not at all to keep composure before the eyes of others, for I am and yet I cannot be, and so, pushing my way through among the multitude, do you See I've come, I'm here, I'm here? Oh my, oh my, to see you Piling up such Suffering unknown in all the world, how you are moreover hung upon a crux, and to what a sorry State you Are reduced, my eyes go dark; my mind fades all away: never will I leave this Crux.

The pillar of stone. Nossa Senhora. $\left[7^{\mathrm{v}}\right]$

How now, O pillar of stone on which Leans the Lord of heaven and earth! He leans upon you not to Make heaven and earth but rather So that his Body may Be mercilessly beaten and torn with thrashings. If the Blood that Flows from the body of the Child $\left(\wedge f^{o}\right)$ could seep into me, I feel we would never part. Since it is the pillar against which this dear child of mine (^dilectos fil.) Presses his Skin, I too will embrace it and worship it as the precious Pillar of heaven.

The rope. Maria Madalena.

From now on we must call this a precious Cord! Since it is the cord which tied up the Hands of the world Helper, oh, what a rare event in all the world, that you should make heaven and earth, then should even enter and bind yourself inside Flesh, and on top of that: this twine which causes such pain that you cannot see! So then, because this cord, in binding the Hands of my sovereign, is the implement which looses the bonds of crime of the world, I do esteem and worship it.

[79] The Whip. Nossa Senhora.

Who can look on this whip without tears? Oh, this Color which it has turned all on its own! Now it has Been dyed so in the vermillion blood-tide: How Colorful it is! It is the Sign of my dear child's Skin and Flesh having been beaten and torn. Oh, how much Blood there is! Some five thousand lashes-each and every time the Pain met your Skin, and now indeed they are beyond counting. Ah, how it Hurts my heart! Since it is stroking the skin of my Child Deus, I do esteem and worship it.

The Crown. Maria Madalena.

How now, O you anjo of the sky! Each of you, Look at this: is not my Lord also the Sovereign of you all? Is this the true Crown which pertains to a king? Oh, 
how terribly sharp the tips of the spines! It is these spines that pierce through the Hair of my Lord for whom I long, even to the Skull of his skin and Flesh. $\left[79^{v}\right]$ Ah, how sad! In sympathy I partake of his Pain, the Pain which passes through to the core of his Body, and never will I ever release it from my heart.

The Garment. Nossa Senhora.

This is the very Garment that I wove and sewed together to be worn by my dear child. Ah, what an unfamiliar Color it is! How now, my Child! This, this is the color of the Blood of your Body! When, having beaten and torn your Skin and Flesh with a thrashing rod, they stripped off this Garment which you Wore bound around you, your Skin and Flesh were separated from your Body and stuck to it—oh, the sadness! Since this day your Skin Is seen, because it is the Clothing of the Helper whose Plans of Cherishing Stand revealed, I do esteem and worship them.

The matter of the crux. Maria Madalena.

Oh, what a precious Crux! This, this is the soft Bed on which the Lord for whom I long so deeply Lies in Sleep of agonizing death. [80] From now on this, this will be the cushion on which I lie back and take my ease. Since it is the Bed on which my Helper Lies, I do esteem and worship it.

The Nails. Maria Madalena.

Oh, what sweet and deeply flavorful nails! They are hard and bitter in that they painfully pierce through the sinewy Hands and Feet of the Helper, but because they are the implements which stick him fast in sweet Cherishing to his Crux so that as long as he lives he will never Leave it, I experience them as truly sweet. Just as he has planned never to Leave his Crux, I pray you, nail me down so I may never leave my Lord! I worship these precious Nails with all my heart.

The Hammer. Maria Madalena.

Oh this precious and hard hammer! How it Makes our two hearts ache with the sound of each stroke! When I hear its sound and think of how it is striking through the Hands and Feet of my Lord, $\left[80^{\mathrm{v}}\right]$ my mind goes all dim. Even to remember it now makes my heart ill at ease; at the sight the wounds in my heart also erupt anew.

The sponja. Nossa Senhora.

Oh this sponja which, when he was weak at heart, receiving even the blame of the criminals of society, beyond even that, by way of administering a medicine to revive him, gave a taste of the bitter thing of a wild animal as a restorative for 
JESUS, who Was hurt and completely exhausted, and by and by this sponja became something that added to his Sufferings. O Sponja, To JESUS bitter, by means of his truly and fully Tasting your bitterness, you are for me a sponja of deep sweetness, and so I do esteem and worship you.

The spear. Nossa Senhora.

Oh how merciless and hateful this spear! Ah, the Pain and Suffering which my sovereign Endured in Life Is just excessive! On top of that, moreover, even after he had Died, this spear pierced through his Side, and so it was the doing of this spear that his grieving mother's heart was stabbed right through. [81] Accordingly what terribly good karma this spear has! Because it is the implement which in this way Opened a spring of life for us in the Breast of the sovereign, I do esteem and worship it.

The meaning of the Passion.

These numerous implements are signs of the way in which our Lord JESUS $\mathrm{X}^{\circ}$, Commanding from Deus Padre to Be hung on a crux as a scapegoat for all the crimes of humanity, pitifully Withstood various sufferings, and so we ought to savor well its meaning.

The stone pillar.

This stone pillar is the implement to which the Lord JESUS $\mathrm{X}^{\circ}$ Was tied and Received some five thousand six hundred strokes with the rod. It is the sign by which we must be tied to the pillar of his Cherishing.

The rope.

This rope is the implement by which the Lord JESUS $X^{\circ}$ was mercilessly bound. It is the sign which Loosens and sets free even the wounds of evil bound to crime.

[81 $]$ Disciplina.

This disciplina is the implement which did beat and break the Body of the Lord JESUS $X^{\circ}$. To wit, it is the sign which Frees us from the denunciation of suffering which we were to receive in inferno.

The crown.

This crown of thorns is the implement by which the LordJESUS $X^{\circ}$ was mocked as king and his Head severely attacked with blows. It is the sign for whose Sake he Looks upon the evil of the vanity of us men and Sends it away. 
His Garment.

This, this is the Clothing which they stripped off our Lord JESUS $\mathrm{X}^{\circ}$ in order to hang him on the crux, and so they roughly peeled off his Skin which had Been torn and broken by the savage rod of beating and bound to it, and so it Is an Undergarment to which his cut Flesh Is stuck.

\section{His Crux.}

Regarding this crux, because Adam of the beginning and his wife Partook of the fruit of the maçã tree, in retribution for their crime he Decreed that they should die right on down to their descendants, but this crux is the sign of the implement on which the Lord JESUS $\mathrm{X}^{\mathbf{0}}$ Was hung and Died, in order to Resurrect them to a life of graça.

[82] The nails.

These nails are the three nails which fixed the Hands and Feet of the Lord JESUS $X^{\circ}$. Because of the deep Mercy of the suffering which he Endured for three hours, they are the implements which Frees us from the sufferings of iustiça in inferno.

The hammer.

This hammer is the hammer with which nails were mercilessly driven into each Hand and Foot of the Lord JESUS $\mathrm{X}^{\mathrm{o}}$. It is the implement that Drives his inescapable Cherishing into us human beings.

\section{The sponja.}

This sponja is not only that by which the Lord JESUS $\mathrm{X}^{\mathrm{o}}$, when he was thirsty Upon the crux and evil men in their deep hatred put bitter things in his Mouth and he Tasted it: it is the implement which throws away bitter evil and Gives us sweet goodness to taste.

The spear.

This pike was savagely stuck into the Right side of the Lord JESUS $\mathrm{X}^{\mathrm{o}}$, but his Blood and water are the implements by which He nourishes human beings their whole lives long and Bestows on them the Life of gloria.

$\left[82^{\mathrm{v}}\right]$ The bamboo.

Regarding this bamboo, it is the implement which, as a sign to scorn and mock the Lord JESUS $\mathrm{X}^{\circ}$, he Held in his Hand. They say this was simply to Show that there is no profit in the myriad things of the world. Thirty mon in silver coin is 
the money that it Caused from the criminal Judas bear. This is the implement which Buys back all humanity which had become vassals of tengu, and so it is the sign of our becoming free.

The pliers.

These pliers are the implement which pulled out the three Nails of the Lord JESUS $X^{\circ}$. These are simply the sign which Grasps and pulls out the evil which we people have driven into our hearts.

Finis Laus Deo.

How now, O Lord JESUS $X^{\circ}$, Have mercy. How now, O Lord JESUS $X^{\circ}$, Have mercy. Forgive the crimes of humanity. 